\title{
List of Referees
}

The Journal of Public Policy operates a review policy of sending papers to referees with the author's name removed. Similarly, the names of referees are not made known to the authors of papers. In order to acknowledge the very valuable contribution which a large number of referees have made to the Journal of Public Policy, we list here in alphabetical order the names of referees who sent in reports received between 1 January ${ }_{198} 8_{4}$ and $3^{1}$ August 1984 .

J. R. Bradshaw, University of York

Gary D. Brewer, Yale University

N. J. Byrne, Dorset Institute for Higher Education

David Dery, Hebrew University of Jerusalem

L. A. Dexter, Johns Hopkins University

John Dryzek, Ohio State University

W. N. Dunn, University of Pittsburgh

Daniel J. Elazar, Jerusalem Institute for Federal Studies

John Foster, Paisley College of Technology

Robert W. Hahn, Carnegie Mellon University

Jack Hayward, University of Hull

J. Hills, Institute for Fiscal Studies, London

R. Hoffenbert, State University of New York, Binghamton

David Houlcroft, University of Birmingham

B. Houlihan, North Staffordshire Polytechnic

David J. Hunter, University of Aberdeen

W. I. Jenkins, University of Kent at Canterbury

Michael Keating, University of Strathclyde

Rudolf Klein, University of Bath

Jan-Erik Lane, University of Umea

J. Le Grand, London School of Economics

Franz Lehner, Ruhr-Universität Bochum

Charles Levine, University of Kansas

G. P. Marshall, University of Sheffield

A. J. Meltsner, University of California, Berkeley

Johan Olsen, University of Bergen

Edward Page, University of Hull

B. Guy Peters, University of Pittsburgh

A. R. Prest, London School of Economics

Jeremy Richardson, University of Strathclyde

Ann Robinson, University of Wales, Cardiff

Cedric Sandford, University of Bath

Stuart Sayer, University of Edinburgh

J. R. Shackleton, Polytechnic of Cientral London

- David Tarr, Federal Trade Commission, Washington

P. Townroe, University of East Anglia

C. G. Veljanovski, Centre for Socio-Legal Studies, Wolfson College, Oxford

David Vogel, University of California, Berkeley

Keith Webb, University of Kent at Canterbury

G. Wenban-Smith, British Gas Corporation

Hal Wolman, Urban Institute 
NOTES FOR CONTRIBUTORS TO THE JOURNAL

Authors are requested to submit their original manuscript plus three copies to:

Professor Richard Rose, Joumal of Public Policy

Centre for the Study of Public Policy

University of Strathclyde

McCance Building, 16 Richmond Street,

Glasgow GI IXQ, Scotland

\section{GENERAL APPROACH}

Authors are asked to bear in mind the nature of the readership when writing their contribution. In particular, care should be taken to draw out the implications of the analysis for readers interested in other policy fields, other countries and other disciplines. Jargon specific to a particular discipline should be avoided, and definitions should be provided for words which might be unfamiliar to many readers.

It should be borne in mind that some readers may not be familiar with complex statistical methodology. Accordingly, verbal statements of major findings should always be included. Statistical points can be discussed in notes. Complex statistical or methodological points might merit an appendix. Where you feel that an understanding of the approach used is important in interpreting the substantive findings it might be advisable to explain this in terms comprehensible to the non-specialist in a 'box' which can be placed at the appropriate point in the text.

Similarly, while the editor recognizes the importance of work that proceeds deductively from high-level theoretical abstractions, articles for this Journal will be expected to show clearly what their substantive significance is in terms of issues arising in a governmental context.

\section{PREPARATION OF MANUSCRIPT}

The entire manuscript, including footnotes and references should be typed double-spaced on one side only of $\mathrm{A}_{4}$ sized paper with a left-hand margin of at least $1 \frac{3}{4}$ inches $\left(4 \frac{1}{2} \mathrm{~cm}\right)$. Manuscript pages should be numbered consecutively.

The title of the article and the author's name and affiliation should be typed on a separate page at the beginning of the article.

The title only should appear on the next page, which should contain an abstract of the article of not more than 150 words.

\section{STYLE}

Spelling, capitalization and punctuation should be consistent within each article. Detailed advice on all matters of style is contained in Judith Butcher's book, Copyediting, Cambridge University Press (1975).

Headings of not more than two grades should be used and they should be typed on separate lines.

Tables and Figures should be numbered consecutively in separate series. Each table or figure should be typed or drawn on a separate sheet.
Every table or figure should have a title or caption and at least one reference in the text to indicate its approximate location.

Notes should be avoided wherever possible. Notes should not be used for bibliographic references (see below). When they must occur, notes should be numbered consecutively throughout the article. They will be printed grouped together at the end of the article as endnotes. Notes should be typed in a single list at the end of the paper, starting on a new page.

Bibliographic citations in the text must include the author's surname and year of publication and may include page references. Complete bibliographic information for each citation should be included in the list of references at the end of the paper. Examples of correct styling for bibliographic citation where the author's name is mentioned in the text are Alford (1975), Biller (1976, 136-7), May and Wildavsky (1978), Ostrom, Parks and Whitaker (1978) and subsequently Ostrom et al. (1978). Otherwise, use, e.g. (Biller, 1976, 136-7).

$R$ ferences should be typed in alphabetical order in a single list at the end of the paper, starting on a new page, using the style of the following examples:

Alford, R. (1975) Health Care Politics. Chicago: University of Chicago Press.

Biller, R. (1976) On tolerating policy and organizational termination: some design considerations, Poligy Sciences, 7, $133-49$.

Campbell, D. (1971) Reforms as experiments. In F. Caro (ed.), Readings in Evaluation Research. New York: Russell Sage.

May, J. and A. Wildavsky (eds.) (1978) The Poligy Cycle. Beverly Hills: Sage.

\section{COPYEDITING AND \\ PROOFREADING OF THE MANUSGRIPT}

The editor and publishers reserve the right to copyedit and proofread all items accepted for publication. Authors will review their copyedited manuscripts only if substantial changes have been made. The editor may find it necessary to return for rewording or retyping manuscripts which do not conform to the requirements about style and typing.

Galley proofs of articles will be sent to authors for correction of typographical errors only. Authors must notify the editorial office of any corrections within one week of receip : or approval will be assumed.

Submission of an article or other item implies that it has not been published or accepted for publication elsewhere. Authors are responsible for obtaining written permission to publish material (such as quotations or illustrations) for which they do not own the copyright. Contributors of material accepted for publication will be asked to assign their copyrights, on certain conditions, to Cambridge University Press.

Each author will receive 50 offprints of his article without charge. Additional copies may be purchased if ordered at proof stage. 


\section{Journal of Public Policy}

ISSN o $143-8$ I $4 \mathrm{X}$

VOLUME $_{4}$ PART $_{4}$ NOVEMBER ${ }_{198}$

\section{CONTENTS}

\section{ARTICLES}

Royst on Greenwood: Incremental Budgeting: Antecedents of Change 277

Roy Rothwell: Technology-Based Small Firms and Regional Innovation

Potential: The Role of Public Procurement

Rob van Tulder: Management of Industrial Change in a Small Country:

The Netherlands

David Совнam: The Nationalisation of the Banks in Mitterand's France:

Rationalisations and Reasons

BOOK REVIEWS

L. S. Robertson, Injuries: Causes, Contrel Strategies, and Public Policy

(B. W. Hogwood); T. L. Beyle and L. Muchmore (eds.), Being Governor: The View from the Office (D. Regan); R. D. McKinlay and A. Mughan, Aid and Arms to the Third World (K. Hartley); K. Dyson and S. Wilks (eds.), Industrial Crisis: A Comparative Study of the State and Industry and G. Shepherd, F. Duchêne and C. Saunders (eds.), Europe's Industries: Public and Private Strategies for Change (S. Young).

\section{LIST OF REFEREES}

INDEX TO VOLUME 4 .

(C) Cambridge University Press 1984

CAMBRIDGE UNIVERSITY PRESS

The Pitt Building, Trumpington Street, Cambridge C B2 IR P

$3^{2}$ East 57 th Street, New York, N.Y. 10022 USA

ro Stamford Road, Oakleigh, Melbourne 3166, Australia

Typeset by Wyvern Typesetting Ltd, Bristol

Printed in the United Kingdom by Universities Press, Belfast 